\title{
Portal net appearance of amino acids in growing pigs fed a barley-based diet with inclusion of three different forage meals
}

\author{
M. Reverter, T. Lundh, H. L. Gonda*, and J. E. Lindberg $\dagger$ \\ Department of Animal Nutrition and Management, Swedish University of Agricultural Sciences, PO Box 7024, S-750 07 \\ Uppsala, Sweden
}

(Received 18 January 1999 - Revised 15 November 1999 - Accepted 11 January 2000)

\begin{abstract}
The net absorption of amino acids (AA) in young pigs fed a barley-based control diet (C) and diets where barley was replaced by $200 \mathrm{~g} / \mathrm{kg}$ fresh weight of dried lucerne (Medicago sativa; L20), white clover (Trifolium repens; W20) or perennial ryegrass (Lolium perenne; PR20) meal was studied. Castrated male pigs were fitted with permanent catheters in the hepatic portal vein and mesenteric artery, and the hepatic portal net absorption of AA was estimated from the porto-arterial plasma concentration differences and the hepatic portal-vein blood flow. In general, the essential AA (EAA) concentrations in the hepatic portal vein reached peak levels $90 \mathrm{~min}$ after feeding and thereafter exhibited a transient decline. Maximum porto-arterial differences were reached between 1 and $3 \mathrm{~h}$ postprandially for most of the AA. The cumulative net absorption of non-essential AA (NEAA) and EAA did not differ significantly between the barley-based diet and diets W20 and PR20. Due to a lower intake of AA on diet L20, the cumulative net absorption of NEAA and EAA was significantly $(P<0.05)$ lower than diet C. With the exceptions of the EAA arginine, cystine and valine, and the NEAA glutamic acid + glutamine and glycine, there were no significant differences in the absorption coefficients for the EAA and NEAA between the diets. In addition, the pattern of the total EAA in the mixture absorbed postprandially did not differ significantly between the diets. The present study gives support to the contention that the replacement of barley AA with forage meal AA in a barleybased diet for growing pigs should be expected to result in minor differences in the net portal flux of AA.
\end{abstract}

Portal vein: Amino acid absorption: Fibre: Forage

Forages have a high content of crude protein $(\mathrm{N} \times 6.25$; $\mathrm{CP})$ with reasonable levels of essential amino acids (EAA), and have the potential to be included in substantial amounts in cereal-based diets for pigs (Wiesemüller \& Poppe, 1990; Vestergaard et al. 1996; Andersson, 1997). In both outdoor and organic pig production, forages are either grazed or fed, and thus make up part of the daily nutrient supply to the animal. However, until recently, limited detailed information has been available on the nutritional properties of forages for pigs.

It has been shown that increasing the inclusion of forage meal in a barley-based diet for growing pigs will decrease the ileal (Lindberg \& Cortova, 1995; Andersson \& Lindberg, 1997a,b) and total tract (Lindberg et al. 1995; Lindberg \& Andersson, 1998) digestibilities of nutrients and energy. Recently, Reverter \& Lindberg (1998) reported that the apparent ileal digestibility of most EAA and nonessential amino acids (NEAA) were not significantly affected by the dietary inclusion of lucerne (Medicago sativa)-leaf meal in a barley-based diet for growing pigs. However, the calculated true ileal digestibilities of most EAA were significantly reduced with the inclusion of lucerne-leaf meal. In accordance with this finding, Reverter et al. (1999) found that the true ileal digestibility of crude protein (CP) and all EAA showed a reduction in barleybased diets with increasing inclusion of lucerne, red clover (Trifolium pratense), white clover (Trifolium repens), and perennial ryegrass (Lolium perenne) meal. In the latter study, there was also a decrease in the apparent ileal digestibility of $\mathrm{CP}$ and of most of the EAA and NEAA

\footnotetext{
Abbreviations: AA, amino acids; C, control diet; CP, crude protein; EAA, essential amino acids; Glx, glutamine + glutamic acid; L20, diet containing lucerne meal; NEAA, non-essential amino acids; PR20, diet containing perennial ryegrass; W20, diet containing white clover.

* Present address: Universidad Nacional del Centro de la Provincia de Buenos Aires, Departmento de Produccion Animal, Tandil, Argentina.

$\dagger$ Corresponding author: Professor J. E. Lindberg, fax +4618 672102, email jan-eric.lindberg@ $@$ huv.slu.se
} 
when forage meals were included in the diets. From these data, it appears likely that the fibrous constituents in forages exert a major influence on the availability of amino acids (AA) to pigs (Reverter \& Lindberg, 1998; Reverter et al. 1999).

In contrast, the accretion of the dietary $\mathrm{CP}$ in growing pigs has been shown to be improved as a result of foragemeal inclusion in the diet (Lindberg \& Cortova, 1995; Lindberg \& Andersson, 1998). This could have been due to a greater digestible EAA intake (from higher contents of $\mathrm{CP}$ and EAA in the forage meals) in conjunction with a smaller decrease in ileal digestibility of EAA (Reverter \& Lindberg, 1998; Reverter et al. 1999). However, it was not possible from the existing data to assess the relative importance of an increase in the intake of fibrous constituents on the utilisation of AA in diets with foragemeal inclusion. In an earlier study, Malmlöf et al. (1988) compared plasma $\alpha$-AA concentration in growing pigs (30-52 kg) fed the same daily amount of CP from a low(barley and fish meal) and a high-fibre diet (barley and fishmeal diet diluted with wheat straw). These authors found a significantly lower postprandial mean portoarterial plasma concentration of free $\alpha$-AA on the highfibre diet. In contrast, Lenis et al. (1996) recently reported that no significant differences could be measured in the mean $\alpha$-AA concentration and in the total flux of $\alpha$-AA in growing pigs fed a semi-purified diet with and without addition of purified wheat bran.

The purpose of the present study, therefore, was to test the hypothesis that the net appearance of AA in the hepatic portal blood in growing pigs, expressed both as a proportion of AA intake and as a proportion of apparently-ileal-digested AA, was comparable in a barley-based diet with and without forage meal inclusion.

\section{Materials and methods}

\section{Experimental design, animals and housing}

Twelve castrated male pigs (Landrace $\times$ Yorkshire) were used for the present experiment. The pigs were fitted with catheters in the portal vein and the mesenteric artery, and an ultrasonic flow probe was fitted to the hepatic portal vein. The pigs were divided into three groups of four; within each group the animals were randomised to the four experimental diets according to a balanced $4 \times 4$ changeover design, repeated three times (Patterson \& Lucas, 1962). Due to malfunction of a number of catheters and problems with some of the AA analyses, complete blood sampling series from both portal vein and mesenteric artery were only possible from five animals. Thus, the number of blood samples analysed for AA content on each diet was limited to three to four per treatment.

The pigs weighed 40 (SD 2.2) $\mathrm{kg}$ at the time of surgery. They were kept in individual pens during adaptation and between blood sampling periods, and were moved to metabolic cages $1 \mathrm{~h}$ before each blood sampling period. To minimise stress, the pigs were trained before the start of the experiment to be moved to, and kept in, metabolism cages during blood sampling periods.
Table 1. Ingredients, chemical composition, gross energy content and mean daily intakes of the control diet (C) and the experimental diets containing lucerne (Medicago sativa; L20), white clover (Trifolium repens; W20) and perennial ryegrass (Lolium perenne; PR20) meal

\begin{tabular}{|c|c|c|c|c|c|}
\hline & \multicolumn{4}{|c|}{ Diet } & \multirow[b]{2}{*}{ SEM } \\
\hline & $\mathrm{C}$ & L20 & W20 & PR20 & \\
\hline \multicolumn{6}{|l|}{ Ingredient (g/kg diet) } \\
\hline Barley & 950 & 750 & 750 & 750 & \\
\hline Lucerne meal & & 200 & & & \\
\hline White clover meal & & & 200 & & \\
\hline Perennial ryegrass meal & & & & 200 & \\
\hline Vitamins and minerals* & 15 & 15 & 15 & 15 & \\
\hline Dicalcium phosphate & 20 & 20 & 20 & 20 & \\
\hline $\mathrm{CaCO}_{3}$ & 8 & 8 & 8 & 8 & \\
\hline $\mathrm{NaCl}$ & 4 & 4 & 4 & 4 & \\
\hline \multicolumn{6}{|l|}{ Chemical composition (g/kg DM) } \\
\hline DM & 928 & 933 & 931 & 931 & \\
\hline Ash & 51 & 64 & 60 & 67 & \\
\hline Crude protein $(\mathrm{N} \times 6.25)$ & 116 & 125 & 135 & 121 & \\
\hline Crude fat & 24 & 22 & 23 & 24 & \\
\hline Starch $^{\dagger}$ & 572 & 458 & 464 & 458 & \\
\hline Sugars $^{\ddagger}$ & 2 & 2 & 4 & 4 & \\
\hline Neutral-detergent fibre & 141 & 210 & 178 & 221 & \\
\hline Gross energy (MJ/kg DM) & $17 \cdot 4$ & $17 \cdot 4$ & $17 \cdot 6$ & $17 \cdot 4$ & \\
\hline \multicolumn{6}{|l|}{ Daily intake (g/d) } \\
\hline DM & 1491 & 1224 & 1417 & 1364 & 84 \\
\hline Crude protein & $174^{\mathrm{ab}}$ & $149^{b}$ & $192^{\mathrm{a}}$ & $166^{a b}$ & 12 \\
\hline
\end{tabular}

${ }^{\mathrm{a}, \mathrm{b}}$ Mean values within a row with unlike superscript letters were significantly different $(P<0.05)$.

* Composition (per $\mathrm{kg}$ ): retinyl acetate $172 \mathrm{mg}$, cholecalciferol $2.5 \mathrm{mg}, \alpha-$ tocopheryl acetate $8.04 \mathrm{~g}$, vitamin $B_{2} 400 \mathrm{mg}$, pyridoxine $200 \mathrm{mg}$, vitamin $\mathrm{B}_{12} 2 \mathrm{mg}$, pantothenic acid $1 \mathrm{~g}$, niacin $800 \mathrm{~g}$, folic acid $100 \mathrm{mg}$, choline chloride $100 \mathrm{~g}$, Se $20 \mathrm{mg}$, Fe 4 g, I 20 mg, Cu 1 g, Mn 2 g, Zn 7 g. $\uparrow$ Starch + maltodextrins

$\ddagger$ Glucose + fructose.

\section{Diets and feeding}

The ingredients and chemical composition of the four diets are shown in Table 1. The diets included a barley-based diet (C) and three diets in which $200 \mathrm{~g}$ barley/kg fresh weight was replaced by the same amount of lucerne (L20), white clover (W20) or perennial ryegrass (PR20) meal. All forages were grown in experimental plots at the Swedish University of Agricultural Sciences, Uppsala, Sweden. They were harvested when in bud or early bloom, transferred into jute sacks and barn-dried at $25^{\circ} \mathrm{C}$ for at least $72 \mathrm{~h}$ or until dry. Barley and forages were hammermilled $(3.0 \mathrm{~mm}$ screen $)$. After mixing, the diets were pelleted (inlet and outlet temperatures were approximately 75 and $80^{\circ} \mathrm{C}$ respectively).

The pigs were fed three times daily, at 8.00, 16.00 and 24.00 hours, in equal amounts. Daily feed intake was restricted to $40 \mathrm{~g} / \mathrm{kg}$ average live weight throughout the experiment. Water was provided ad libitum.

\section{Blood sampling, measurements and calculations}

After a post-surgery recovery period of $5 \mathrm{~d}$, the pigs were assigned to one of the four dietary treatment groups according to the experimental plan. The adaptation period to each diet was $7 \mathrm{~d}$ and blood sampling started on day 8 . Blood sample collection started 30 min before feeding and 
continued until $8 \mathrm{~h}$ after feeding, thus covering one feeding interval. Blood samples were withdrawn every $30 \mathrm{~min}$ during the first $2 \mathrm{~h}$ and once every hour thereafter. At each sampling $15 \mathrm{ml}$ blood was taken from each catheter (portal vein and mesenteric artery). A proportion of whole blood from each sample was drawn into a micro-haematocrit capillary tube and centrifuged at $10000 \mathrm{~g}$ for $3 \mathrm{~min}$ to determine packed cell volume. The rest of the blood samples were collected in centrifuge tubes containing EDTA and immediately placed on ice. After centrifugation (3500 $\mathrm{g}$ for $10 \mathrm{~min}$ at $4^{\circ} \mathrm{C}$ ), the plasma was stored at $-80^{\circ} \mathrm{C}$ until free AA analysis was performed. During sampling sessions physiological saline ( $9 \mathrm{~g} \mathrm{NaCl} / \mathrm{l})$ containing heparin (100 IU heparin/ml) was used for flushing the catheters. Blood flow was registered continuously from 5 min before blood sample collection until $5 \mathrm{~min}$ after the blood sample was collected.

The absorption of AA was calculated according to the formula:

$$
Q=(C p-C a) D d t
$$

where $(\mathrm{Cp}-\mathrm{Ca})$ represents the porto-arterial differences in the AA concentration, $D$ is the blood flow rate in the portal vein and $Q$ is the amount absorbed within the time interval $d t$ (Rérat et al. 1980).

The flux of AA into the portal vein was calculated from the differences in concentration of AA in portal and arterial blood (analysed plasma AA concentration $\times(1-$ packed cell volume in each sample)) multiplied by the corresponding portal-vein blood flow rate (Rérat et al. 1980). During the experiment mean packed cell volume did not differ $(P>0.05)$ with period of treatment. From the fluxes measured at regular intervals after the meal, the cumulative flux over the period of $8 \mathrm{~h}$ between two meals was also calculated. Due to nonsignificant differences in hepatic portal-vein blood flow between pigs and between diets, and the fact that the quality of all individual blood-flow measurements was not found to be acceptable, the mean blood flow ( $\mathrm{ml} / \mathrm{min}$ per $\mathrm{kg})$ at each sampling time, obtained in four pigs, was used for the calculations for individual pigs, based on their live weight. This approach resulted in similar results to those obtained from individual flows and AA concentrations in pigs where complete data were available. The blood flows $(\mathrm{ml} / \mathrm{min}$ per $\mathrm{kg}$ ) used in the calculations were 29 (SD 2·3), 35 (SD 2.0), 36 (SD 3.1), 35 (SD 2.5), 34 (SD 4.5), 33 (SD 1.7), 31 (SD 2.1), 29 (SD 1.5), $30(\mathrm{SD} 5 \cdot 0), 28(\mathrm{SD} 0 \cdot 5), 28(\mathrm{SD} 1 \cdot 5)$ and $28(\mathrm{SD} 1.8)$ at sampling times $0,+30,+60,+90,+120,+180,+240,+300$, $+360,+420,+450$ and $+480 \mathrm{~min}$ in relation to feeding respectively.

The AA absorption coefficients were calculated with regard to either the AA intake $(\mathrm{g} / 8 \mathrm{~h})$ or the amount of ileal AA digested (Reverter et al. 1999), according to the formula:

$$
\frac{\text { AA appearing in the portal vein }}{\text { AA intake or AA digested }} \text {. }
$$

A similar approach was used for the patterns of the EAA in the mixture absorbed and for the mixture of EAA ingested.

\section{Analytical procedures}

Analysis of plasma AA was performed by HPLC (Reverter et al. 1997). With this method, the within- and betweenassay reproducability for the determination of plasma AA, the $\mathrm{CV}$, have been shown to be below 2.2 and $4.5 \%$ respectively. The recovery of AA in spiked plasma samples ranged from 94 to $106 \%$, except for histidine and tyrosine which both showed a recovery of $80 \%$. The method used is valid for detection of AA in blood plasma down to 1$6 \mu \mathrm{mol} / \mathrm{l}$, except for cystine where the detection limit was $14 \mu \mathrm{mol} / \mathrm{l}$ due to a much lower relative fluorescence response. In order to be sure about the quantification of lysine and phenylalanine, the plasma samples were analysed using two different elution profiles (for details, see Reverter et al. 1997). All AA concentrations in the present paper are expressed on a whole-blood basis. The analysed values in plasma were corrected by their corresponding packed cell volume as these tended to be lower in the blood of animals fed the control diet during the post-absorptive stage (from 3 to $7 \mathrm{~h}$ after feeding).

All feed analyses were performed on freeze-dried samples. Chemical analyses of diets were performed according to conventional procedures, as described by Andersson \& Lindberg (1997a). AA contents of the experimental diets were determined by HPLC using the AccQ.Tag ${ }^{\circledR}$ (6-aminoquinolyl- $N$-succinimidyl carbamate reagent; Waters Assoc., Milford, MA, USA) method (Cohen \& De Antonis, 1994). Samples were hydrolysed for $24 \mathrm{~h}$ at $110^{\circ} \mathrm{C}$ with $6 \mathrm{M}-\mathrm{HCl}$ containing $2 \mathrm{mg}$ reagentgrade phenol/ml and $5000 \mathrm{nmol}$ norleucine (external standard) in evacuated and sealed ignition tubes. Halfcystine and methionine were determined as cysteic acid and methionine sulphone respectively, with separate samples oxidised with performic acid overnight at $0^{\circ} \mathrm{C}$ and thereafter hydrolysed for $24 \mathrm{~h}$ as described earlier (Moore, 1963).

\section{Statistical analyses}

Due to the methodological problems described earlier ( $\mathrm{p}$. 484), the experimental data were analysed using a generalised least square analysis with the proc mixed procedure (SAS statistical software package, version 6.03; SAS Institute, Cary, NC, USA). The model used was:

$$
\mathrm{Y}_{\mathrm{ijk}}=\mu+\mathrm{T}_{\mathrm{i}}+\beta_{\mathrm{j}}+\pi_{\mathrm{k}}+\mathrm{a}_{\mathrm{ij}}+\mathrm{e}_{\mathrm{ijk}}
$$

where $\mu$ is the overall mean, $T_{i}$ is the fixed treatment effect, $\beta_{\mathrm{j}}$ is the fixed block effect, $\pi_{\mathrm{k}}$ is the fixed period effect, $\mathrm{a}_{\mathrm{ij}}$ is the random effect of the animals within the blocks, and $e_{i j k}$ is the overall error of the model. $a_{i j}$ and $e_{i j k}$ were assumed to be independent and normally distributed. The effects of dietary treatment on AA concentrations and AA fluxes were determined for each sampling time and for the means over the $8 \mathrm{~h}$ measuring period. Treatment mean differences were tested by pair-wise comparisons. Results are presented as least squares means with the highest standard error calculated for each AA and each diet. 
Table 2. Content $(\mathrm{g} / 16 \mathrm{~g} \mathrm{~N})$ of essential (EAA), non-essential (NEAA) and total amino acids (AA), and the proportions of EAA and NEAA relative to total $A A$, in the control diet $(C)$ and the experimental diets containing lucerne (Medicago sativa; L20), white clover (Trifolium repens; W20) or perennial ryegrass (Lolium perenne; PR20) meal $^{*}$

\begin{tabular}{|c|c|c|c|c|}
\hline Diet. . . & $\mathrm{C}$ & L20 & W20 & PR20 \\
\hline \multicolumn{5}{|l|}{ EAA } \\
\hline Arginine & $5 \cdot 2$ & $5 \cdot 0$ & $5 \cdot 2$ & $5 \cdot 0$ \\
\hline Cystine & $4 \cdot 2$ & $3 \cdot 9$ & 3.9 & 3.9 \\
\hline Histidine & $2 \cdot 2$ & $2 \cdot 2$ & $2 \cdot 1$ & $2 \cdot 0$ \\
\hline Isoleucine & 3.5 & $3 \cdot 7$ & $3 \cdot 7$ & $3 \cdot 6$ \\
\hline Leucine & $6 \cdot 7$ & $6 \cdot 7$ & $6 \cdot 7$ & $6 \cdot 8$ \\
\hline Lysine & $3 \cdot 7$ & $3 \cdot 8$ & $3 \cdot 8$ & 3.7 \\
\hline Methionine & 1.6 & 1.4 & 1.4 & 1.5 \\
\hline Phenylalanine & $5 \cdot 1$ & 4.9 & $5 \cdot 0$ & $5 \cdot 0$ \\
\hline Threonine & 3.5 & $3 \cdot 6$ & 3.5 & 3.4 \\
\hline Tyrosine & $3 \cdot 2$ & $3 \cdot 3$ & $3 \cdot 3$ & $3 \cdot 1$ \\
\hline Valine & 4.9 & $5 \cdot 0$ & $5 \cdot 0$ & $5 \cdot 1$ \\
\hline \multicolumn{5}{|l|}{ NEAA } \\
\hline Alanine & $3 \cdot 7$ & $4 \cdot 1$ & $4 \cdot 1$ & 4.2 \\
\hline Aspartic acid & $5 \cdot 7$ & $7 \cdot 1$ & $6 \cdot 8$ & $6 \cdot 2$ \\
\hline Glutamic acid & 21.9 & $18 \cdot 3$ & $17 \cdot 3$ & 19.5 \\
\hline Glycine & 3.9 & 3.9 & 4.0 & 3.9 \\
\hline Proline & $10 \cdot 7$ & $10 \cdot 2$ & 9.9 & $10 \cdot 7$ \\
\hline Serine & 4.4 & 4.5 & 4.4 & $4 \cdot 2$ \\
\hline Total AA & $94 \cdot 1$ & $91 \cdot 6$ & $90 \cdot 1$ & $91 \cdot 8$ \\
\hline EAA & $46 \cdot 5$ & 47.5 & 48.4 & 46.9 \\
\hline NEAA & 53.5 & 52.5 & 51.6 & $53 \cdot 1$ \\
\hline
\end{tabular}

* For details of composition of diets, see Table 1.

\section{Results}

Feed intake

The health of the pigs was good. Daily feed allowances were consumed with some refusals in the diets with foragemeal inclusion. The proportion of EAA in the diets with forage-meal inclusion was higher than in the control diet (Table 2). As a result of differences in chemical composition, the average intake of CP differed $(P<0.05)$ between the diets (Table 1). There were also differences $(P<0.05)$ in the average intake of crude fat, starch and sugars between the diets (data not shown).

\section{Hepatic portal-vein amino acid concentrations}

Most of the free EAA in the hepatic portal vein reached peak levels by 90 min after feeding and exhibited a decline thereafter. However, immediately after feeding (30 min), a rapid increase in the concentrations of most of the EAA (arginine, isoleucine, leucine, lysine, phenylalanine, tyrosine and valine) was seen in pigs fed the C and W20 diets (Table 3; data for lysine and valine not shown). For most of the NEAA the maximum levels in hepatic portal blood were slightly delayed, as compared with the EAA, and were reached between 90 and 120 min after feeding (Table 4).

The postprandial absorption patterns for most EAA were similar in the four different diets. There were very small changes in the hepatic portal vein concentrations of the EAA, cystine, histidine and methionine, and the NEAA, hydroxyproline and aspartic acid, during the postprandial period for all diets. There were also small changes in the postprandial concentrations of asparagine in diet PR20 (Table 4) and citrulline on diet W20 (data not shown).

\section{Arterial amino acid concentrations}

The postprandial concentrations of most EAA and NEAA in arterial blood showed similar increases to those in the hepatic portal vein, although the increases were much smaller (Tables 3 and 4). The exceptions were the arterial concentration of cystine for all diets, and phenylalanine for diets L20 and PR20, which were found to remain constant during the postprandial period. The arterial concentrations of aspartic acid and hydroxyproline also showed little change during the post-absorptive period (data not shown).

\section{Porto-arterial differences in amino acid concentration}

The postprandial porto-arterial differences were generally large and positive for all diets, and there were no ambiguities about the direction of the flux of the AA. However, the differences were sometimes very small. Temporal reverses in the direction of the flux during the postprandial period, as for the sum of glutamine + glutamic acid (Glx), were noted. The maximum postprandial portoarterial differences were found between $1-3 \mathrm{~h}$ after feeding for most of the EAA and NEAA (data not shown). The mean total blood EAA concentration $(\mathrm{mg} / \mathrm{l})$ in the portal vein and mesenteric artery in each sampling period, and for each diet, are presented in Fig. 1. Vein concentrations were significantly higher $(P<0.05)$ than arterial concentrations in most of the sampling periods. However, the differences were smaller in the samples collected before and during the meal and in the last sample taken, compared with the samples taken immediately after feeding.

\section{Cumulative net appearance of amino acids}

There were no significant differences in the cumulative net appearance of total EAA on diets C, W20 and PR20 during the $8 \mathrm{~h}$ postfeeding period. However, the cumulative net appearance of total EAA on diet L20 was significantly lower $(P<0.05)$ than those for the other diets (Table 5$)$. This finding was due to a lower absorption for most of the EAA, although only the cumulative net appearances of histidine and leucine were found to be significantly $(P<$ $0.05)$ lower than those for the other three diets.

The cumulative net appearances of cystine and valine were significantly lower $(P<0.05)$ on diet W20 than on diets C and PR20, while the cumulative net appearances of histidine, methionine and tyrosine were significantly lower $(P<0.05)$ on diet PR20 than on diets $\mathrm{C}$ and W20.

The cumulative net appearances of the total NEAA during the $8 \mathrm{~h}$ postfeeding period was also lower $(P<$ $0.05)$ on diet L20 than those for diets $\mathrm{C}$ and W20, and the difference appeared to be due mainly to a lower $(P<0.05)$ cumulative net appearance of Glx with diet L20 than with the other diets. No significant differences in the cumulative net appearances of alanine, aspartic acid, citrulline, ornithine, proline and taurine were observed between the diets. A positive cumulative net absorption of Glx was only found with diet $\mathrm{C}$ (Table 5). 
Table 3. Hepatic portal vein and arterial concentrations ( $\mu \mathrm{mol} / \mathrm{l}$; on a whole blood basis ${ }^{*}$ ) of essential amino acids (EAA) in pigs fed a control diet (C) and experimental diets containing lucerne (Medicago sativa; L20), white clover (Trifolium repens; W20) and perennial ryegrass (Lolium perenne; PR20) meal†

(Mean values with their pooled standard errors for three to four observations)

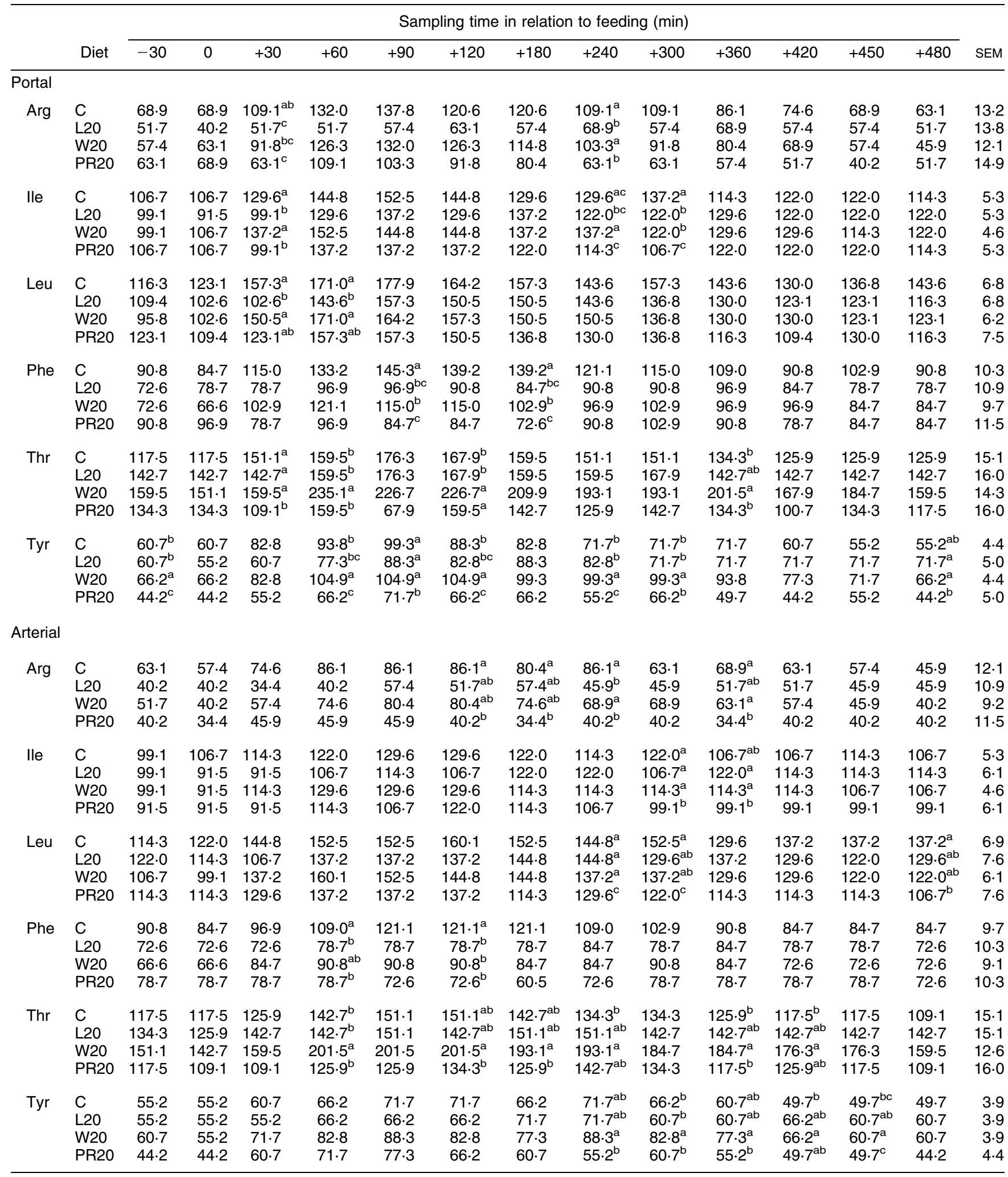

a,b,c Mean values within a row with unlike superscript letters were significantly different $(P<0.05)$

* Calculated from measured values in plasma corrected by their corresponding packed cell volume. Average packed cell volume ( $n 52)$ : portal blood 27.6 (SD 1.79$) \%$; arterial blood 27.5 (SD 1.91) \%.

† For details of diets, see Tables 1 and 2. For details of procedures, see p. 484. 
Table 4. Hepatic portal vein and arterial concentrations ( $\mu \mathrm{mol} / \mathrm{l}$; on a whole blood basis*) of the non-essential amino acids (NEAA) in pigs fed a control diet (C) and experimental diets containing lucerne (L20), white clover (W20) and perennial ryegrass (PR20) meal $\dagger$

(Mean values with their pooled standard errors for three to four observations)

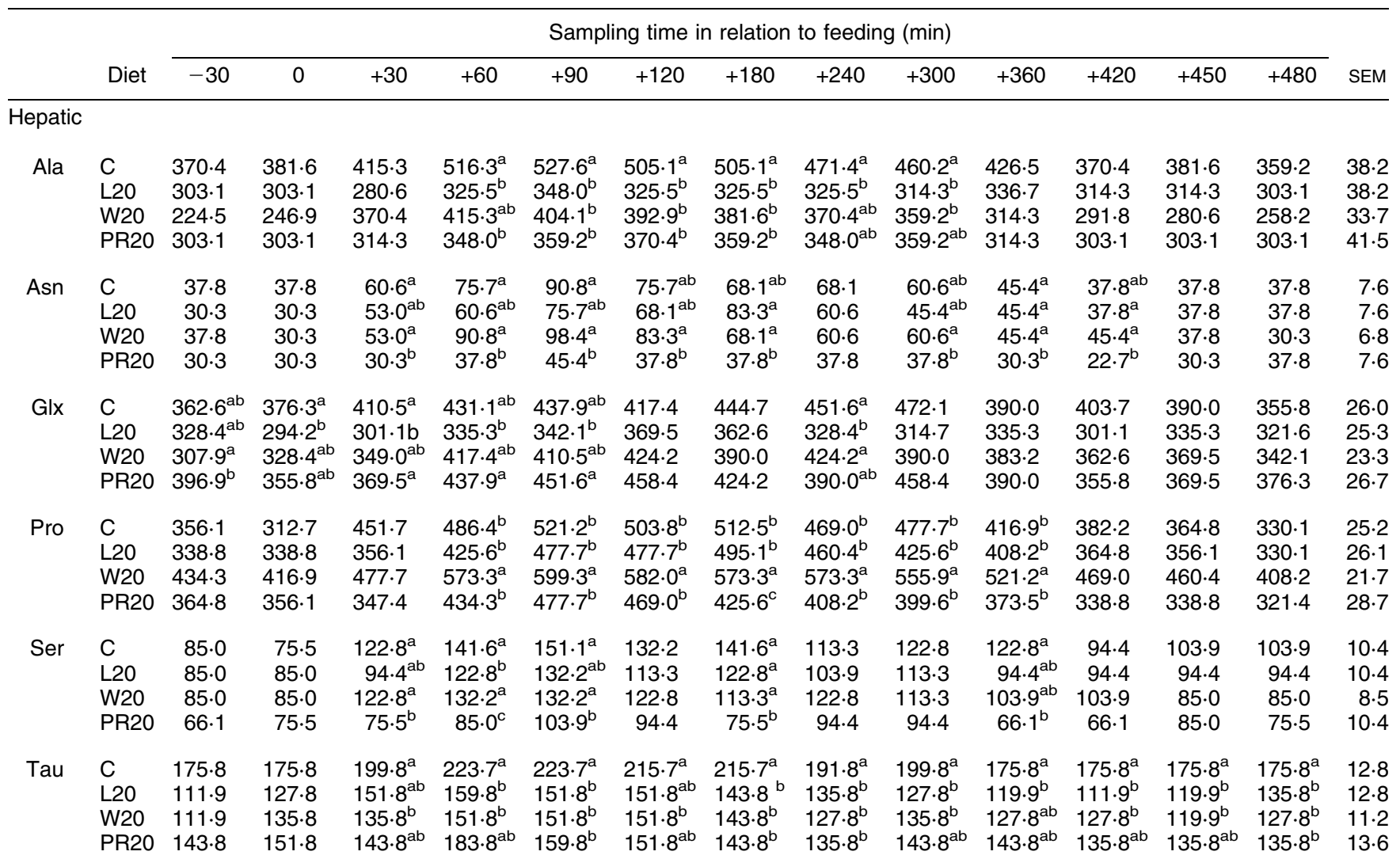

Arterial

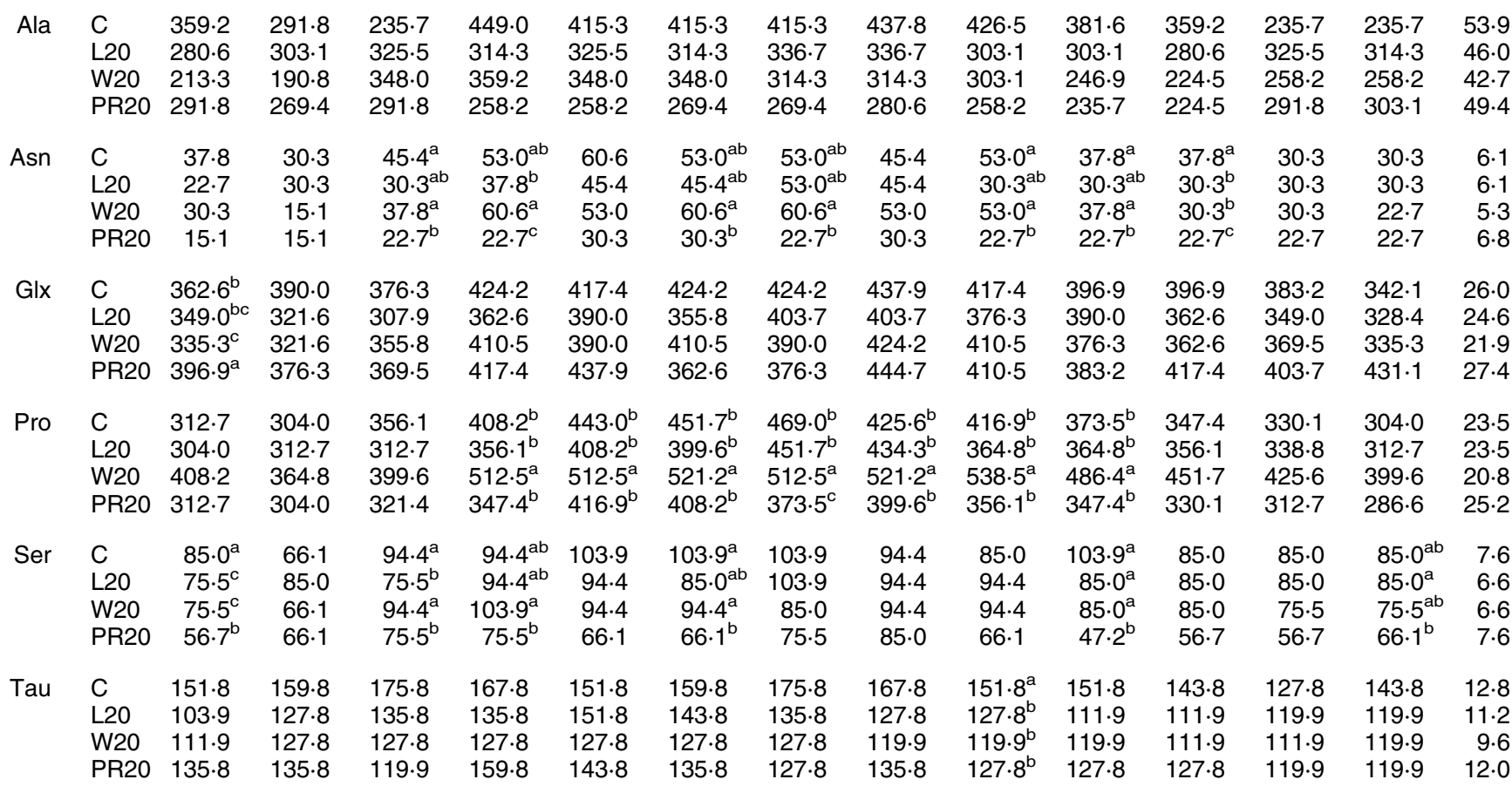

\footnotetext{
${ }_{\mathrm{a}, \mathrm{b}, \mathrm{c}}$ Mean values within a row with unlike superscript letters were significantly different $(P<0.05)$

* Calculated from measured values in plasma corrected by their corresponding packed cell volume. Average packed cell volume ( $n 52)$ : portal blood 27.6 (SD 1.79$) \%$, arterial blood 27.5 (SD 1.91) \%.
}

† For details of diets, see Tables 1 and 2. For details of procedures, see p. 484. 


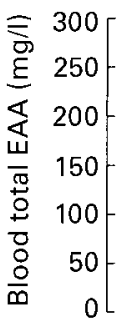

(a) C
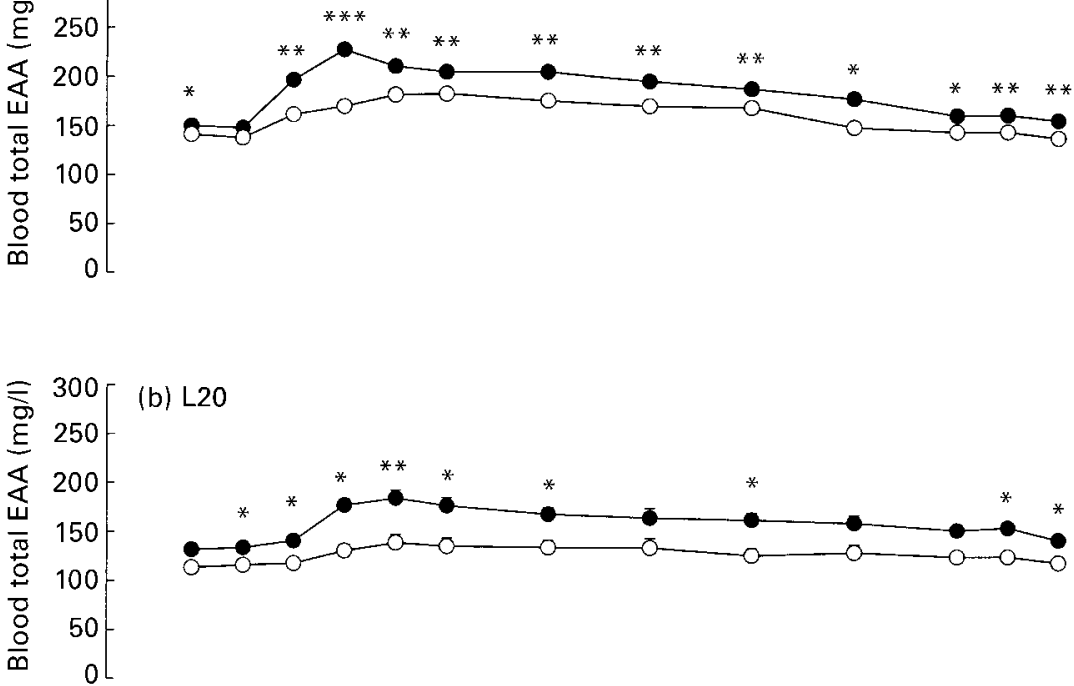

(b) L20

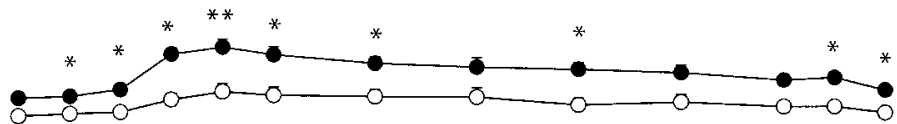

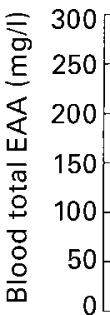

(c) $W 20$
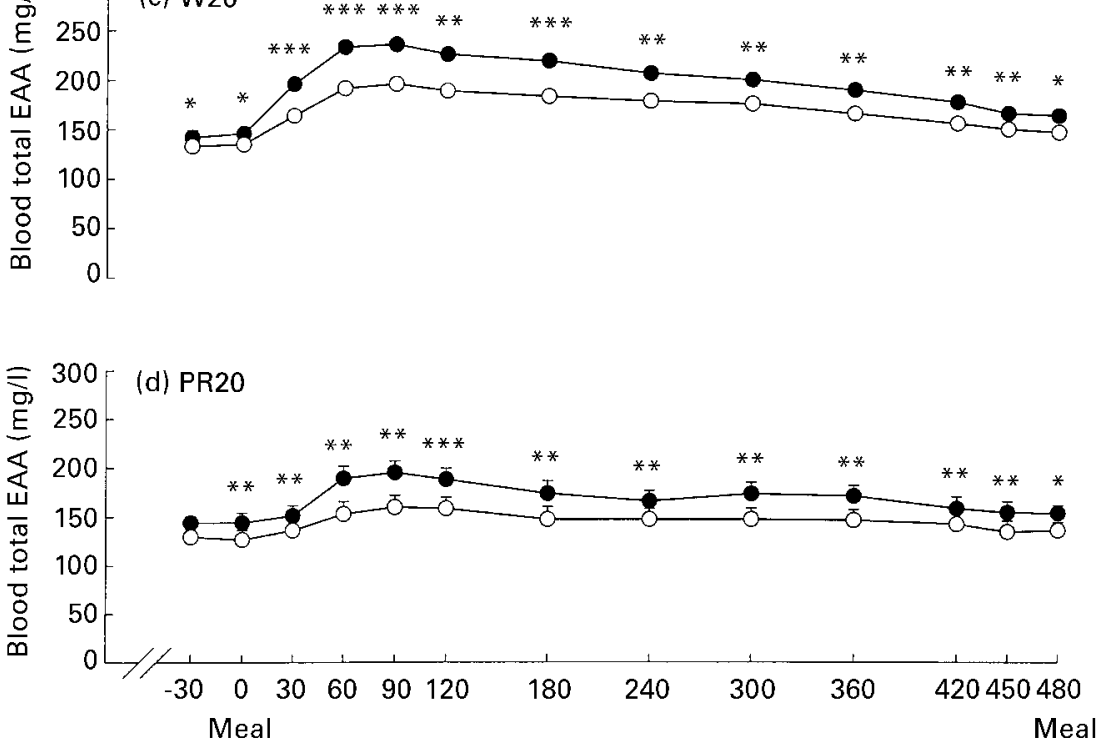

Time $(\mathrm{min})$

Fig. 1. Total blood plasma essential amino acid (EAA) concentrations (mg/l) over an $8 \mathrm{~h}$ period between two meals in the portal vein $(\bullet)$ and mesenteric artery $(O)$ of pigs fed on (a) a control diet (C) and on diets containing (b) lucerne (Medicago sativum; L20), (c) white clover (Trifolium repens; W20) or (d) perennial ryegrass (Lolium perenne; PR20) meal. Values are least square means with their standard errors represented by vertica bars. Significant differences in total EAA concentration between the vein and artery are indicated for each sampling time: ${ }^{\star} P<0.05,{ }^{\star \star} P<0.01$, ${ }^{\star \star \star} P<0.001$. For details of diets and procedures, see Tables 1 and 2 and p. 484.

\section{Absorption coefficients}

There were no significant differences between diets in the absorption coefficients for the total EAA, or for most of the individual EAA, absorbed $8 \mathrm{~h}$ postprandially in relation to the EAA intake (Table 6). On all diets, the absorption coefficient for EAA was higher than that for NEAA (data not shown). Moreover, the absorption coefficient for total EAA calculated as a proportion of the total ileal EAA digested, and for most individual EAA, was not different between the diets (Table 6).

\section{Composition of the amino acid mixture absorbed}

There were no significant differences in the average proportion of total EAA absorbed (in relation to total EAA ingested) among the experimental diets. However, 
Table 5. Cumulative net appearance ( $\mathrm{mg} / \mathrm{kg}$ body weight) of essential (EAA) and non-essential (NEAA) amino acids over an $8 \mathrm{~h}$ postprandial period in pigs fed a control (C) diet and diets containing lucerne (Medicago sativa; L20), white clover (Trifolium repens; W20) or perennial ryegrass (Lolium perenne; PR20) meal*

(Mean values with their pooled standard errors for twelve pigs)

\begin{tabular}{|c|c|c|c|c|c|}
\hline & \multicolumn{4}{|c|}{ Diets } & \multirow[b]{2}{*}{ SEM } \\
\hline & C & L20 & W20 & PR20 & \\
\hline \multicolumn{6}{|l|}{ EEA } \\
\hline Arginine & $35 \cdot 0$ & $44 \cdot 4$ & $60 \cdot 5$ & $50 \cdot 3$ & $9 \cdot 6$ \\
\hline Cystine & $27 \cdot 5^{\mathrm{a}}$ & $18 \cdot 9^{a b}$ & $11 \cdot 8^{\mathrm{b}}$ & $21.9^{\mathrm{a}}$ & $2 \cdot 4$ \\
\hline Histidine & $27 \cdot 6^{\mathrm{a}}$ & $17 \cdot 5^{\mathrm{C}}$ & $27 \cdot 0^{\mathrm{a}}$ & $23 \cdot 0^{\mathrm{b}}$ & 0.7 \\
\hline Isoleucine & $31 \cdot 4^{\mathrm{ab}}$ & $24 \cdot 4^{\mathrm{b}}$ & $34.9^{a}$ & $34.7^{\mathrm{a}}$ & $2 \cdot 2$ \\
\hline Leucine & $49 \cdot 5^{\mathrm{a}}$ & $38 \cdot 4^{b}$ & $52 \cdot 0^{\mathrm{a}}$ & $52 \cdot 3^{\mathrm{a}}$ & 1.9 \\
\hline Lysine & $35 \cdot 6^{\mathrm{ab}}$ & $31 \cdot 1^{\mathrm{b}}$ & $40 \cdot 8^{a}$ & $32 \cdot 8^{\mathrm{ab}}$ & 3.5 \\
\hline Methionine & $12 \cdot 8^{\mathrm{a}}$ & $8 \cdot 6^{\mathrm{b}}$ & $12 \cdot 4^{\mathrm{a}}$ & $8 \cdot 6^{\mathrm{b}}$ & $1 \cdot 0$ \\
\hline Threonine & $28 \cdot 6^{\mathrm{ab}}$ & $23 \cdot 2^{b}$ & $33 \cdot 0^{\mathrm{a}}$ & $35 \cdot 5^{\mathrm{a}}$ & 1.7 \\
\hline Tyrosine & $39 \cdot 4^{\mathrm{a}}$ & $30 \cdot 4^{b}$ & $40 \cdot 4^{a}$ & $23 \cdot 1^{\mathrm{c}}$ & $2 \cdot 0$ \\
\hline Phenylalanine & $43 \cdot 7^{\mathrm{ab}}$ & $27 \cdot 7^{\mathrm{b}}$ & $45 \cdot 3^{\mathrm{a}}$ & $32 \cdot 3^{\mathrm{ab}}$ & $3 \cdot 6$ \\
\hline Valine & $57 \cdot 7^{\mathrm{a}}$ & $38 \cdot 2^{b}$ & $28 \cdot 0^{C}$ & $61 \cdot 3^{\mathrm{a}}$ & $2 \cdot 1$ \\
\hline Total EAA & $395 \cdot 6^{\mathrm{a}}$ & $289 \cdot 0^{\mathrm{b}}$ & $375 \cdot 3^{\mathrm{a}}$ & $368 \cdot 4^{\mathrm{a}}$ & $19 \cdot 3$ \\
\hline \multicolumn{6}{|l|}{ NEAA } \\
\hline Alanine & $97 \cdot 3$ & $68 \cdot 8$ & $74 \cdot 0$ & $69 \cdot 0$ & $12 \cdot 5$ \\
\hline Asparagine & $36 \cdot 3^{a}$ & $32 \cdot 7^{\mathrm{a}}$ & $35 \cdot 3^{\mathrm{a}}$ & $19 \cdot 2^{b}$ & 3.9 \\
\hline Aspartic & $5 \cdot 6$ & $8 \cdot 8$ & 11.6 & $9 \cdot 8$ & 1.8 \\
\hline Citrulline & $26 \cdot 0$ & $25 \cdot 1$ & $41 \cdot 7$ & 26.9 & 8.6 \\
\hline Glx & $39 \cdot 2^{a}$ & $-77 \cdot 2^{b}$ & $-3 \cdot 1^{\mathrm{a}}$ & $-10 \cdot 7^{a}$ & 23.9 \\
\hline Glycine & $74 \cdot 8^{\mathrm{a}}$ & $52 \cdot 9^{b}$ & $67 \cdot 0^{\mathrm{ab}}$ & $51 \cdot 1^{\mathrm{b}}$ & $4 \cdot 0$ \\
\hline OH-Proline & $7 \cdot 6^{\mathrm{ab}}$ & $6 \cdot 1^{\mathrm{b}}$ & $9 \cdot 0^{\mathrm{a}}$ & $7 \cdot 4^{\mathrm{ab}}$ & 0.67 \\
\hline Ornithine & $33 \cdot 6$ & $27 \cdot 6$ & $28 \cdot 1$ & 33.4 & $6 \cdot 6$ \\
\hline Proline & 92.5 & 85.4 & $91 \cdot 2$ & $79 \cdot 2$ & $5 \cdot 0$ \\
\hline Serine & $41.4^{a}$ & $32 \cdot 6^{\mathrm{b}}$ & $39 \cdot 6^{a}$ & $26 \cdot 3^{c}$ & $3 \cdot 0$ \\
\hline Taurine & $23 \cdot 8$ & $20 \cdot 2$ & $26 \cdot 0$ & 29.9 & $1 \cdot 2$ \\
\hline Total NEEA & $494 \cdot 8^{\mathrm{a}}$ & $258 \cdot 5^{\mathrm{b}}$ & $438 \cdot 6^{\mathrm{a}}$ & $343 \cdot 9^{a b}$ & $30 \cdot 1$ \\
\hline
\end{tabular}

Glx, glutamic acid + glutamine.

$a, b, c$ Mean values within a row with unlike superscript letters were significantly different $(P<0.05)$.

${ }^{\star}$ For details of diets, see Tables 1 and 2. For details of procedures, see p. 484.

significant $(P<0.05)$ differences for some of the individual EAA, such as cystine, lysine, methionine, threonine, tyrosine and valine (Fig. 2), and for all NEAA except alanine were found. A lower $(P<0.05)$ proportion of Glx was recovered in the hepatic portal blood of pigs fed L20

Table 6. Absorption coefficients of essential amino acids (EAA) appearing in the portal vein of pigs over an $8 \mathrm{~h}$ postfeeding period calculated as a proportion of EAA intake and as a proportion of total apparently-ileal-digested EAA (Reverter et al. 1999)*

(Mean values with their standard errors across diets)

\begin{tabular}{lccccc}
\hline & \multicolumn{2}{c}{ EAA intake } & & \multicolumn{2}{c}{ EAA digested } \\
\cline { 2 - 3 } \cline { 5 - 6 } & Mean & SEM & & Mean & SEM \\
\hline Total EAA & 0.61 & 0.07 & & 0.82 & 0.09 \\
Arginine & 0.62 & 0.07 & & 0.78 & 0.10 \\
Cystine & 0.37 & 0.04 & & 0.49 & 0.05 \\
Histidine & 0.83 & 0.07 & & 1.14 & 0.09 \\
Isoleucine & 0.64 & 0.08 & & 0.92 & 0.07 \\
Leucine & 0.52 & 0.05 & 0.69 & 0.06 \\
Lysine & 0.69 & 0.11 & 0.90 & 0.14 \\
Methionine & 0.53 & 0.07 & 0.76 & 0.05 \\
Phenylalanine & 0.55 & 0.08 & 0.72 & 0.05 \\
Threonine & 0.63 & 0.08 & 1.10 & 0.13 \\
Tyrosine & 0.76 & 0.10 & & 1.01 & 0.12 \\
Valine & 0.71 & 0.08 & 0.93 & 0.08 \\
\hline
\end{tabular}

${ }^{\text {* }}$ For details of diets, see Tables 1 and 2. For details of procedures, see p. 484. compared with the other diets, in contrast to a higher $(P<$ 0.05 ) proportion of glycine and serine (Fig. 3).

\section{Discussion}

The present study shows that inclusion of forage fibre in a barley-based diet for pigs did not affect the absorption coefficients of most AA. Moreover, although there were differences for some of the individual EAA, the overall pattern of the EAA in the mixture absorbed $8 \mathrm{~h}$ postprandially did not differ between diets. This finding is in agreement with that of Lenis et al. (1996) who found no effects of the inclusion of fibre on the hepatic portal flux of AA in pigs fed a basal diet with inclusion of $15 \%$ purified neutral-detergent fibre derived from wheat bran.

The rapid postprandial increase in portal vein and arterial AA concentrations and the subsequent gradual decrease found in the present study were in agreement with the findings of other researchers (Malmöf et al. 1988; Rérat et al. 1988a; Galibois et al. 1989; Lenis et al. 1996). The absorption coefficients for AA in the barley-based diet, with a faster absorption of histidine and the aromatic amino acids than of the $\mathrm{S}$ amino acids, were also in general agreement with the findings of other studies (Rérat et al. 1979; Rérat, 1980). The mixture of NEAA absorbed underwent changes in the same direction as that reported by Rérat et al. (1979), with a large apparent excess of alanine and glycine and large deficiencies of aspartic and glutamic acid. The negative porto-arterial differences found for Glx in some of the samples on all diets suggested a net uptake of glutamine by the intestine (Rérat et al. 1976). Large negative porto-arterial differences for glutamine across the intestine have been reported in different animal species (Windmueller \& Spaeth, 1974). Most of the glutamine uptake and metabolism has been suggested to take place in the small-intestinal mucosal cells, and appears to proceed via glutamic acid. The AA taken up by the intestine, mainly dietary glutamic acid, dietary and arterial glutamine and dietary aspartic acid, may be oxidised to produce energy and serve as precursors in protein synthesis (Rérat \& Corring, 1991). Contrary to the control diet, negative absorption values were obtained for Glx in the diets with forage-meal inclusion. This finding might have been the result of a higher rate of gut metabolism, probably due to the effects of dietary fibre on the intestinal mucosa (Bergner et al. 1975).

In the present study, the amount of total AA absorbed $8 \mathrm{~h}$ after the control diet feeding was lower than that for diet L20, but not those for the other diets with forage-meal inclusion. The absorption coefficients for the EAA and NEAA, although smaller, were not significantly lower on diet L20. This finding might be attributed to a lower AA intake since DM, and therefore CP intake, were lower on diet L20 than on the other diets. However, a higher endogenous secretion which could change the relative net absorption EAA and NEAA and/or result in a higher uptake of AA by the gut wall (Wu, 1998) is also a possibility. The elevated proportions of glycine, proline and serine found in the mixture absorbed with diet L20, and the low recovery for Glx with diet L20 compared with the other diets, 


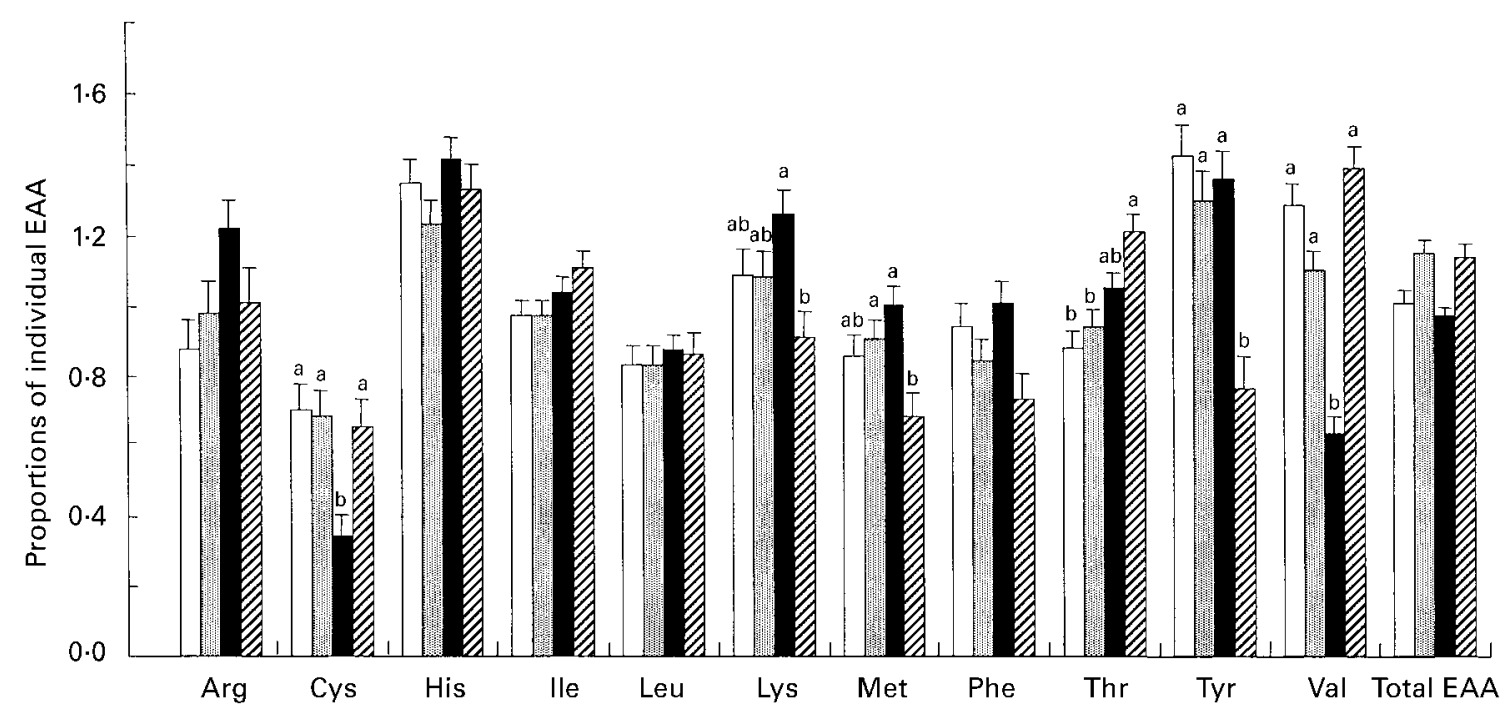

Fig. 2. Proportions of individual essential amino acids (EAA) in the absorbed mixture with regard to their corresponding proportions in the ingested mixture over an $8 \mathrm{~h}$ postprandial period in pigs fed a control diet $(\square)$ and diets containing lucerne (Medicago sativa; $⿴$ ), white clover (Trifolium repens; $\mathbf{\square}$ ) or perennial ryegrass (Lolium perenne; $\mathbb{Q}$ ) meal. Values are least square means with their standard errors represented by vertical bars. ${ }^{a, b}$ Mean values not sharing a common supercript letter were significantly different $(P<0.05)$. For details of diets and procedures, see Tables 1 and 2 and p. 484.

suggests that a higher endogenous secretion and a higher uptake of glutamine and glutamic acid by the gut might have occurred with this diet.

On the control diet the absorption coefficients of the total EAA and NEAA during the $8 \mathrm{~h}$ period were 0.66 and 0.55 respectively, after ingestion of $58 \mathrm{~g}$ barley $\mathrm{CP}$. These proportions are, on average, higher than the absorption coefficients obtained after ingestion of $100 \mathrm{~g}$ barley CP (Rérat et al. 1979). Moreover, the absorption coefficients of arginine, cystine and valine in the present study were found to be much greater than the values reported by Rérat $e t$ al. (1979). This finding suggests a relative decrease in the coefficients of AA absorption when the amount of barley protein ingested is increased, although the total amount of AA absorbed in venous blood will increase when the protein intake is increased (Rérat et al. 1988b; Rérat, 1990; Simoes Nunes et al. 1991). The decrease in the absorption depends on the particular AA and on the source of protein (Rérat et al. 1988a,b). This finding might be due to a saturation of the absorptive capacities of the intestine, particularly during the first hours after feed ingestion when the intake of protein is high (Rérat, 1990). Arginine and cystine are the AA in cereals which show a poor absorption, which could indicate that these AA are more efficiently absorbed at low levels of protein intake. No explanation has been found for the high absorption

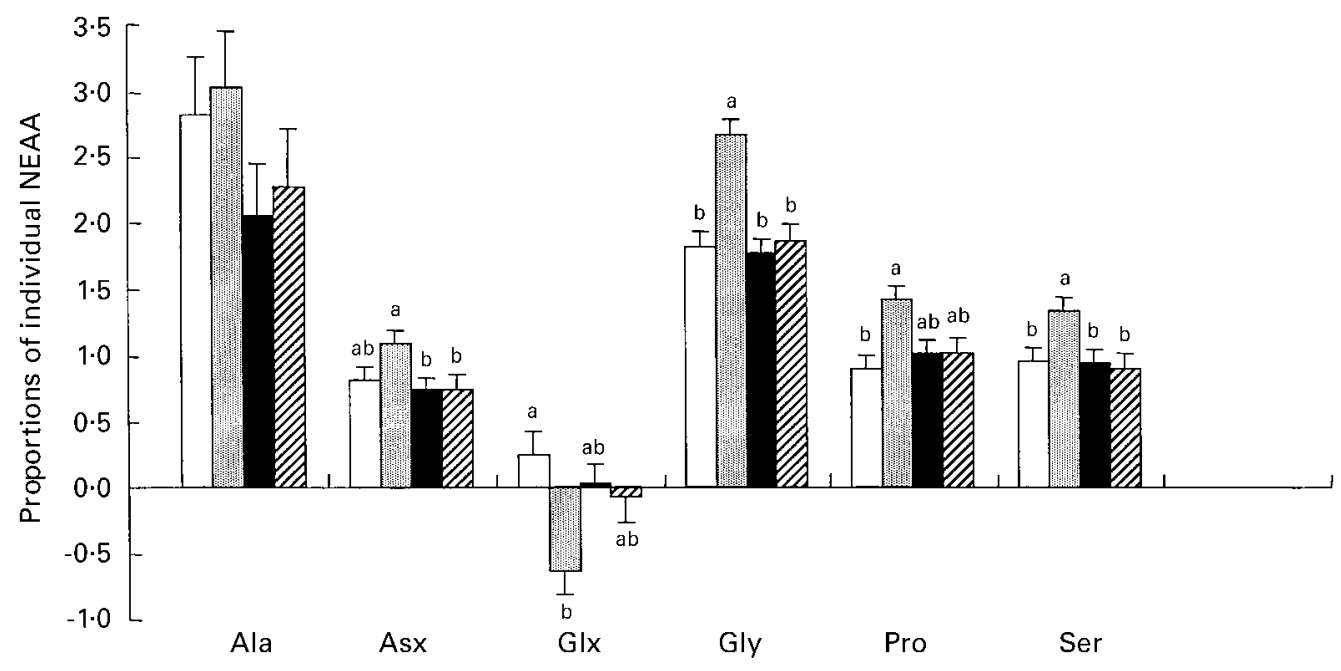

Fig. 3. Proportions of individual non-essential amino acids (NEAA) in the absorbed mixture with regard to their corresponding proportions in the ingested mixture over an $8 \mathrm{~h}$ postprandial period in pigs fed a control diet $(\square)$ and diets containing lucerne (Medicago sativa; $⿴ 囗 0)$, white clover

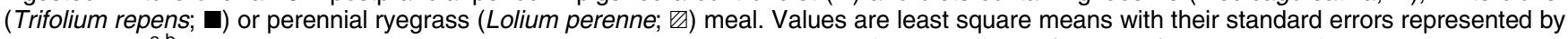
vertical bars. ${ }^{a, b}$ Mean values not sharing a common superscript letter were significantly different $(P<0.05)$. For details of diets and procedures, see Tables 1 and 2 and p. 484. 
coefficient of valine. The pattern of the total EAA in the mixture absorbed did not change markedly with foragemeal inclusion compared with that obtained after feeding barley CP. Variations in the composition might be attributed to changes in the relative amounts of AA taken up by the intestinal wall and to the relative proportions of endogenous $\mathrm{N}$.

The results obtained for the portal blood uptake of apparently-ileal-digested EAA (Reverter et al. 1999) suggest that approximately $82 \%$ of the digested EAA appeared in the hepatic portal blood. Some AA, including histidine, threonine, tyrosine and valine, were absorbed in larger amounts on certain diets, whereas other AA, such as cystine, leucine or phenylalanine, seemed to be absorbed to a lesser extent. This discrepancy between digested and absorbed EAA could be due to absorption of peptides (only free AA were measured), synthesis of protein from AA in the intestinal wall and/or catabolism of absorbed AA by the intestinal mucosa and the rest of the portal-drained viscera. There appears to be no available quantitative data on the absorption of small peptides in pigs, and data from ruminants are conflicting. Recently, Koeln et al. (1993) reported that high amounts of proteins were absorbed as small peptides in calves, whereas Backwell et al. (1996) reported that peptides were absorbed only to a minor extent in goats. The portal hepatic vein constitutes the main route of absorption of AA (Rérat, 1980), but protein-hydrolysis products do not only appear as free AA in the hepatic portal blood; they also appear in the form of proteins synthesised in the intestinal wall (Aliev et al. 1978). It is also possible that absorbed AA were utilised by the intestinal mucosa (Biolo et al. 1992; Matthews et al. 1993). In addition, a higher and more efficient AA absorption might have occurred, but due to a continuous utilisation of arterial AA by the portal-drained viscera, the true portal absorption would have been underestimated (Yu et al. 1990).

In the present study the NEAA ornithine, citrulline, hydroxyproline and taurine appeared in the hepatic portal blood, but were not present in the diets. This finding could be due to metabolism in the arteries and to modification of absorbed AA in the digestive tract. The latter process could thus also change the proportions of absorbed AA relative to the dietary content. Citrulline and ornithine are metabolites of the urea cycle and are synthesised in the intestinal wall in large amounts (Pion et al. 1964). In the present study, the contribution of citrulline to the composition of the mixture of the NEAA absorbed $8 \mathrm{~h}$ postprandially when feeding barley was comparable with that reported by Rérat et al. (1979) in pigs fed a barley diet. However, the proportion was lower than that in the diets with forage-meal inclusion. In contrast, the proportion of ornithine was higher than the value reported by Rérat et al. (1979), and higher for the L20 and PR20 diets than for the W20 and control diets. The high proportion of ornithine and citrulline found after the forage-meal inclusion, together with the low recovery of Glx, gives further support to an increase in the rate of gut metabolism with increasing fibre intake. An increase in the ileal flow of ornithine was also reported by Reverter et al. (1999) in pigs given a barley-based diet with inclusion of $20 \%(\mathrm{w} / \mathrm{w})$ lucerne and perennial ryegrass meal, which might explain the large amount absorbed in these diets. The increase in the ileal flow of ornithine could be attributed to its synthesis from arginine in the small intestine, induced by an increase in the gut microflora and due to the high level of fibre present in those diets (Reverter et al. 1999). However, the amount of arginine absorbed in the present experiment, although lower with the L20 and PR20 diets than with the W20 and control diets, was still higher than expected. This finding could be due to the estimated blood concentration of arginine, as difficulties in the separation of arginine from an unknown compound in some of the blood samples were experienced. This factor could have resulted in an overestimation of the arginine absorption in the present study.

In addition to dietary arginine (Windmueller \& Spaeth, 1976), ornithine synthesis in the enterocytes can be derived from dietary aspartic acid, which may explain the low recoveries found for asparagine and aspartic acid in the present experiment. Furthermore, recent work (Wu, 1997) has shown that proline could be a precursor of ornithine, citrulline and arginine in enterocytes from $0-58$-d-old pigs. Thus, proline might have been contributing to the high amounts of ornithine found in the present study. During the metabolism of glutamine by the intestinal mucosa cells various metabolites are synthesised, including alanine, citrulline and proline (Windmueller \& Spaeth, 1974; Wu, 1998). The large excess of alanine found in the portal blood in the present study can be explained by synthesis from glutamic acid, glutamine, ornithine and citrulline (Rérat, 1982; Rérat et al. 1988b). The very low absorption of aspartic acid and glutamic acid might be explained by their involvement in the synthesis of alanine, ornithine and citrulline. It has been established that taurine may be synthesised from cystine (Hayes, 1985), which could explain the low absorption found for this AA in all diets in the present experiment.

In conclusion, the present work gives an insight into the kinetics of appearance of AA in the portal blood in pigs as related to the inclusion of dietary fibre from forages in a barley-based diet. Although there were changes in the pattern of particular AA in the mixture absorbed, the absorption coefficients of most of the AA did not change significantly among the different diets. The results reported give support to the contention that the replacement of barley AA with forage-meal AA in a barley-based diet for growing pigs should be expected to result in minor differences in the net portal flux of AA.

\section{Acknowledgement}

The authors wish to thank Dr Sigvard Thomke for valuable discussions and comments on the manuscript.

\section{References}

Aliev AA, Ataev UI \& Blinov VI (1978) Synthesis of plasma proteins in the gastrointestinal tract of animals. Vestnik Sel'skohoziaistvennoi Nauki/Vashni, USSR 1, 54-62.

Andersson C, (1997) Forages for growing pigs - partition of digestion and nutritive value. $\mathrm{PhD}$ Thesis, Swedish University of Agricultural Sciences. Acta Universitatis Agriculturae Sueciae, Agraria 31. 
Andersson C \& Lindberg JE (1997a) Forages in diets for growing pigs. 1. Nutrient apparent digestibilities and partition of nutrient digestion in barley-based diets with inclusion of lucerne and white clover meal. Animal Science 65, 483-491.

Andersson C \& Lindberg JE (1997b) Forages in diets for growing pigs. 2. Nutrient apparent digestibilities and partition of nutrient digestion in barley-based diets including red-clover and perennial ryegrass meal. Animal Science 65, 493-500.

Bergner H, Simon O \& Zimmer M (1975) Einfluß des Gehaltes nativer Rohfaser in Diaeten von Ratten auf die Aminosäurenresoption (Influence of crude fibers in the diet of rats on the absorption of amino acids). Archives für Tierernährung 25, 95 104.

Biolo G, Tessari P, Inchiostro S, Bruttomesso D, Frongher C, Sabadin L, Fratton MG, Valerio A \& Tiengo A (1992) Leucine and phenylalanine kinetics during mixed meal ingestion: a multiple tracer approach. American Journal of Physiology 262, 455-463.

Backwell FRC, Bequette BJ, Wilson D, Metcalf JA, Franklin MF, Beever DE, Lobley GE \& MacRae JC (1996) Evidence for the utilization of peptides for milk protein synthesis in the lactating dairy goat in vivo. American Journal of Physiology 271, R955R960.

Cohen SA \& De Antonis KM (1994) Applications of amino acid derivatization with 6-aminoquinolyl-N-hydroxysuccinimidyl carbamate. Analysis of feed grains, intravenous solutions and glycoproteins. Journal of Chromatography 661A, 25-34.

Galibois I, Simoes Nunes C, Rérat A \& Savoie L (1989) Net appearance of amino acids in portal blood during the digestion of casein or rapeseed meal proteins in the pig. Canadian Journal of Physiology and Pharmacology 67, 1409-1417.

Hayes KC (1985) Taurine requirement in primates. Nutrition Reviews 43, 65-70.

Koeln LL, Schlagheck TG \& Webb KE Jr (1993) Amino acid flux across the gastrointestinal tract and liver of calves. Journal of Dairy Science 76, 2275-2285.

Lenis NP, Bikker P, van der Meulen J, Van Diepen JThM, Bakker JGM \& Jongbloed AW (1996) Effect of dietary neutral detergent fiber on ileal digestibility and portal flux of nitrogen and amino acids and on nitrogen utilization in growing pigs. Journal of Animal Science 74, 2687-2699.

Lindberg JE \& Andersson C (1998) The nutritive value of barleybased diets with forage meal inclusion for growing pigs based on total tract digestibility and nitrogen utilization. Livestock Production Science 56, 43-52.

Lindberg JE \& Cortova Z (1995) The effect of increasing inclusion of lucerne leaf meal in a barley-based diet on the partition of digestion and on nutrient utilization in pigs. Animal Feed Science and Technology 56, 11-20.

Lindberg JE, Cortova Z \& Thomke S (1995) The nutritive value of lucerne leaf meal for pigs based on digestibility and nitrogen utilization. Acta Agriculturae Scandinavica 45A, 245-251.

Malmöf K, Simoes Nunes C \& Örberg J (1988) Effects of high dietary fibre level on postprandial porto-arterial differences in the plasma concentrations of immnoreactive insulin, glucose and free amino acids in the growing pig. Swedish Journal of Agricultural Research 18, 67-75.

Matthews DE, Marano MA \& Campbell RG (1993) Splanchnic bed utilization of leucine and phenylalanine in humans. American Journal of Physiology 264, 109-118.

Moore S (1963) On the determination of cystine as cysteic acid. Journal of Biological Chemistry 238, 235-237.

Patterson DH \& Lucas HL (1962) Change-over designs. Technical Bulletin no. 147. Raleigh, NC: North Carolina State College Agricultural Experimental Station.

Pion R, Fauconneau C \& Rérat A (1964) Variation de la composition en acides aminés du sang porte au cours de la digestion chex le porc (Variations in the amino acid composition of the portal blood during digestion in the pig). Annales de Biologie Animale Biochimie Biophysique 4, 383-402.

Rérat A (1980) Some quantitative aspects of protein and carbohydrate absorption in the pig. Proceedings of the Nutrition Society 39, 177-184.

Rérat A (1982) Absorption des sucres et des acides aminés chez le porc (Sugar and amino acid absorption in the pig). In Physiologie Digestive chez le Porc, Les Colloques de l'INRA no. 12, pp. 63-85 [JP Laplace, T Corring and A Rérat, editors]. Paris: Institut National de la Recherche Agronomique.

Rérat A (1990) Absorption of nitrogen and amino acids from exogenous (fish meal proteins) or endogenous sources in the pig. Pig News and Information 11, 173-180.

Rérat A \& Corring T (1991) Animal factors affecting protein digestion and absorption. In Proceedings of the Vth International Symposium on Digestive Physiology in Pigs. European Association for Animal Production publication no. 54, pp. 5-34 [MWA Verstegen, J Huisman and LA den Hartog, editors]. Wageningen: Pudoc.

Rérat A, Corring T \& Laplace JP (1976) Protein digestion and absorption. In Protein Metabolism and Nutrition. European Association for Animal Production Publication no. 16, pp. 97138 [DJA Cole, KN Boorman, PJ Buttery, D Lewis, RJ Neale and H Swan, editors]. London: Butterworths.

Rérat A, Jung J \& Kandé J (1988b) Absorption kinetics of dietary hydrolysis products in conscious pigs given diets with different amounts of fish protein. 2. Individual amino acids. British Journal of Nutrition 60, 105-120.

Rérat A, Vaissade P \& Vaugelade P (1979) Absorption kinetics of amino acids and reducing sugars during digestion of barley or wheat meals in the pig: Preliminary data. Annales de Biologie Animale Biochemie Biophysique 19, 739-747.

Rérat A, Vaissade P \& Vaugelade P (1988a) Absorption kinetics of dietary hydrolysis products in conscious pigs given diets with different amounts of fish protein. 1. Amino-nitrogen and glucose. British Journal of Nutrition 60, 91-104.

Rérat A, Vaugelade P \& Villiers P (1980) A new method for measuring the absorption of nutrients in the pig: critical examination. In Current Concepts of Digestion and Absorption in Pigs, pp. 177-217 [AG Low and IG Partridge, editors]. Reading, Berks: NIRD.

Reverter M \& Lindberg JE (1998) Ileal digestibility of amino acids in pigs given a barley-based diet with increasing inclusion of lucerne leaf meal. Animal Science 67, 131-138.

Reverter M, Lundh T \& Lindberg JE (1997) Determination of free amino acids in pig plasma by precolumn derivatization with 6$\mathrm{N}$-aminoquinolyl-N-succinimidyl carbamate and high-performance liquid chromatography. Journal of Chromatography 696B, 1-8.

Reverter M, Lundh T \& Lindberg JE (1999) Ileal amino acid digestibilities in pigs of barley-based diets with inclusion of lucerne (Medicago sativa), white clover (Trifolium repens), red clover (Trifolium pratense) and perennial ryegrass (Lolium perenne). British Journal of Nutrition 82, 139-147.

Simoes Nunes C, Galibois I, Rérat A, Savoie L \& Vaugelade P (1991) Hepatic and portal-drained viscera balances of amino acids, insulin, glucagon and gastrin in the pig after the ingestion of casein or rapeseed proteins. Reproduction, Nutrition, Development 31, 217-231.

Vestergaard EM, Danielsen V, Eklundh Larsen A \& Bejerholm C (1996) Grønmel til slagtesvin og draegtige søer (Dried grass meal for finishing pigs and pregnant sows). Statens Husdyrbrugsfors $\varnothing$ g. Landbrugs- og Fiskeriministeriet. Forskingsrapport no. 50. Tjele, Denmark: Danish Institute of Animal Science. 
Wiesemüller W \& Poppe S (1990) Lucerne silage as a feedstuff for sows. World Review of Animal Production 25, 47-53.

Windmueller HG \& Spaeth AE (1974) Uptake and metabolism of plasma glutamine by the small intestine. Journal of Biological Chemistry 249, 5070-5079.

Windmueller HG \& Spaeth AE (1976) Metabolism of absorbed aspartate, asparagine and arginine by rat small intestine in vivo. Archives of Biochemistry and Biophysics 175, 670-676.

Wu G (1997) Synthesis of citrulline and arginine from proline in enterocytes of postnatal pigs. American Journal of Physiology 277, 1382-1390.

Wu G (1998) Intestinal mucosal amino acid catabolism. Journal of Nutrition 128, 1249-1252.

Yu YM, Wagner DA, Tredget EE, Walaszewski JA, Burke JF \& Young VR (1990) Quantitative role of splanchnic region in leucine metabolism: L- $\left[1-{ }^{13} \mathrm{C},{ }^{15} \mathrm{~N}\right]$ leucine and substrate balance studies. American Journal of Physiology 259, E36E51. 